\title{
Humusica 2, article 9: Histic humus systems and forms - Specific terms, diagnostic horizons and overview
}

Augusto Zanella ${ }^{a, *}$, Rein De Waal ${ }^{b}$, Bas Van Delft ${ }^{b}$, Jean-François Ponge ${ }^{c}$, Bernard Jabiol ${ }^{d}$, Maria De Nobili ${ }^{\mathrm{e}}$, Chiara Ferronato ${ }^{\mathrm{f}}$, Jean-Michel Gobat ${ }^{\mathrm{g}}$, Andrea Vacca ${ }^{\mathrm{h}}$

${ }^{a}$ University of Padua, Italy

${ }^{\mathrm{b}}$ University of Wageningen, The Netherlands

${ }^{\mathrm{c}}$ Muséum National d'Histoire Naturelle, Paris, France

${ }^{\mathrm{d}}$ AgroParisTech, Paris, France

e University of Udine, Udine, Italy

${ }^{\mathrm{f}}$ University of Bologna, Bologna, Italy

${ }^{\mathrm{g}}$ University of Neuchâtel, Switzerland

${ }^{\mathrm{h}}$ University of Cagliari, Italy

Keywords: Humus; Histic humus; Peat; Submerged soils; Submerged humipedon classification

\section{ABSTRACT}

This paper presents the specific terms of vocabulary and diagnostic horizons necessary for a field classification of submerged Histic humipedons (peats, moors). It is simply an exposition of definitions placed side by side with photographic samples, with rather practical interest. The knowledge reported here is mandatory for people wanting to use the key of classification of these humipedons presented in Humusica 2, article 10. The paper illustrates with schemes the spatial and functional relationships between diagnostic horizons of different Histic humipedons.

\footnotetext{
* Corresponding author.

E-mail addresses: augusto.zanella@unipd.it (A. Zanella), rein.dewaal@wur.nl (R. De Waal), bas.vandelft@wur.nl (B.Van Delft), ponge@mnhn.fr (J.-F. Ponge), bernard.jabiol@agroparistech.fr (B. Jabiol), maria.denobili@uniud.it (M. De Nobili), chiara.ferronato2@unibo.it (C. Ferronato), jeanmichel.gobat@unine.ch (J.-M. Gobat), avacca@unica.it (A.Vacca).
} 


\section{Introduction: submerged humipedon classification}

Submerged humus systems correspond to humipedons (organic and organic-mineral horizons as well) always submerged and/or emerged only a few days per year (Fig. 1). These conditions of anoxia delay the process of biodegradation and the thickness of organic layers may even increase to several metres. In the European Humus Forms Reference Base (Zanella et al., 2011a, b) these humipedons were called Histoforms and were included in a larger group of Semi-terrestrial humus forms. The present version of this international classification resumes the preceding publications (Zanella et al., 2011a, b) and shares ancient Histic, novel Aqueous and ancient Terrestrial humipedons, proposing two intergrades between Histic and Terrestial systems (Epihisto and Hydro), as illustrated in Fig. 1. Histic humipedons often correspond to well-detected and described Histosols, following methods proposed by main international soil classifications (AFES, 2009; Soil Survey Staff, 2014; IUSS Working Group WRB, 2015). Aqueous humus systems were introduced for classifying tidal and subtidal seashores. Even if arduous, this attempt to share moor (Histic) and sea-side/tidalic (Aqueous) systems allows to better circumscribe two main phenomena related to waterlogged soils, corresponding to the lack of oxygen or anoxia and the presence of more or less saline water. Both factors strongly influence the biodegradation of soil organic matter. They slow down the process, favouring the genesis of thick organic horizons.

Bearing in mind the classification of Terrestrial humus systems and forms, a similar scheme has been elaborated for Submerged categories, using as close as possible conceptual bases. Even if slowed down by anoxia, the process of biodegradation of plant remains can be perceived in the soil profile as a series of overlapping horizons. Nevertheless, there are major differences with Terrestrial humus systems. In periodically submerged circumstances the zone of biological changes is to be found in the aerated zone, i.e. the top horizons of the humus profile. Lower organic layers are watersaturated and therefore subjected to a much slower degradation than surface layers. As a consequence, a Terrestrial OH layer cannot be fully compared with a Histic HS horizon. The unaltered organic layers act as a kind of parent material in Histic humus systems, while in Terrestrial humus systems parent materials are strictly mineral.

For clarifying the relationships between the different submerged humus systems, the matter has been parted in four articles: the present paper presents specific terms, diagnostic horizons of Histic systems; article 10 contains an illustrated key of classification of Histic systems; article 11 is dedicated to the intergrades and dynamic relationships between Histic and Hydro terrestrial systems; article 12 presents the new Aqueous humus systems and their tidalic and subtidalic units.

\section{Specific terms of submerged humus systems}

Fibric component. Non-decomposed or very weakly decomposed hygrophilous plant remains like pieces of Sphagnum mosses (Fig. 2), willows, sedges, rushes, reeds... Whole plants, parts of them and/or free plant organs (leaves, needles, twigs, wood, roots...). 
Sapric component. Homogeneous dark organic or organic-mineral matter comprised of well decomposed plant remains partly mixed or not with mineral particles (Fig. 3). Plant structures are not visible to the naked eye or with a 5-10x magnifying hand lens. Animal droppings are possible in periodically aerated horizons and can be abundant in drained peats (shifting to HUMIC COMPONENT of Terrestrial systems).

\section{Diagnostic horizons of submerged humus systems}

There are organic and organic-mineral diagnostic horizons, generally superposed, the firsts at the top and progressively transformed in the seconds which are accessible in digging through different layers of organic material.

\subsection{Histic organic horizons (HF, HM, HS)}

Organic horizons submerged and/or water-saturated for a protracted period of the year (usually more than 6 months per year); carbon content 20\% or more (approximately 35-40\% organic matter) by weight in dry samples, without living roots (Method: element analyser; ISO 10694, 1995). Horizons still under saturated circumstances or drained.

A minimum thickness of horizons for description, diagnosis and sampling purposes has been established at $3 \mathrm{~mm}$. Below this threshold, the horizon is considered discontinuous if clearly in patches or absent if indiscernible from surrounding horizons. Following the rate of fibric and sapric components, histic organic horizons have been divided in three diagnostic horizons HF, HM and HS (Fig. 4). Though named differently ( $\mathrm{HF}=\mathrm{Hi}$ or $\mathrm{Oi} ; \mathrm{HM}=\mathrm{He}$ or $\mathrm{Oe} ; \mathrm{HS}=\mathrm{Ha}$ or $\mathrm{Oa}$ or $\mathrm{L}$ ), these horizons are the same as those used in the main international soil taxonomies (IUSS Working Group WRB, 2015 AFES, 2009; Soil Survey Staff, 2014) for describing peat soils. Focusing on a simplified field key, with a structure nearing the one used for Terrestrial humipedons (Humusica 1, article 4), we prepared the definitions of Histic diagnostic horizons reported in the following paragraphs.

\subsubsection{HF (from histic and fibric)}

Histic organic horizon consisting almost entirely of practically un- changed plant remains. Fibric component $\geq 90 \%$, sapric component $<10 \%$ of horizon volume (Figs. 4 and 5). Content of rubbed fibres (Levesque and Dinel, 1977; Levesque et al., 1980; Green et al., 1993) $\geq 40 \%$ of soil by dry weight $\left(105^{\circ} \mathrm{C}\right)$. von Post scale of decomposition: $1-3$ (4, 5 possible). Close to the Soil Survey Staff (2014) definition of Fibric Soil Material. Plant remains from Sphagnum mosses, willows, sedges, rushes and reeds are recognizable. Fibric horizons are quite common in bogs and oligotrophic parts of isolated fens. These horizons are mainly composed of remains of Sphagnum and Eriophorum species. In mesotrophic fens, the HF-horizon is mainly composed of remains of sedges and rushes. 
Fibric horizons in eutrophic fens are less common because of faster decomposition in those environments.

\subsubsection{HM (from histic and mesic)}

Histic organic horizon consisting of half-decomposed organic ma- terial not fitting the definition of fibric (HF) or sapric (HS) horizons. Fibric component $10 \%-70 \%$, sapric component $90 \%-$ $30 \%$ by volume (Figs. 4 and 6 ). Content of rubbed fibres (Levesque and Dinel, 1977; Levesque et al., 1980; Green et al., 1993): $10-40 \%$ of soil by dry weight (soil dried at $105^{\circ} \mathrm{C}$ ), von Post scale of decomposition: 4-7 (8 possible). Close to the Soil Survey Staff (2014) definition of Hemic Soil Material.

\subsubsection{HS (from histic and sapric)}

Histic organic horizon in advanced stage of decomposition. Sapric component $\geq 70 \%$ of the horizon volume; fibric component less than $30 \%$ (Fig. 4). Content of rubbed fibres (Levesque and Dinel, 1977; Levesque et al., 1980; Green et al., 1993) < $10 \%$ of soil by dry weight (soil dried at $70^{\circ} \mathrm{C}$ ). von Post scale of decomposition: 8 to 10. Close to the Soil Survey Staff (2014) definition of Sapric Soil Material, sapric horizons of brook valley systems and around wells have mostly a higher amount of mineral fraction than those in fens or bogs. Although at first sight quite similar, the horizons can differ in structure, $\mathrm{pH}$, nutrient content and base saturation due to differences in water quality, vegetation and soil organisms.

There are three HS types (suffixes: zo, noz, I):

O zoHS = Meso or macrostructured HS horizon with a high activity of soil animals, especially earthworms and/or aquatic worms and other meso and micro fauna. The mineral fraction is less than $50 \%$ (Fig. 7). Typically present in drained Histic humus forms (both naturally and artificially drained). Activity of meso and micro fauna is high. The mineral fraction (clay, loam and/or sand) is commonly high compared to that of fibric horizons. Worms other than earthworms are present in submerged horizons, in particular Tubificidae, which is another family of annelids playing a prominent role in the transformation of organic matter in such a context. They are poorly studied, but it is highly probable that they are the main soil engineers in submerged environments, and maybe the main actors of the transformation of fibric component into sapric component and in the mixing of organic matter with mineral matter, in addition to water movements.

o nozHS = Massive HS horizon with low activity of soil animals. Common around bogs and rain-fed ponds. Humification mainly results from the activity of microorganisms, which is typical of oligotrophic environments. Complexes of humic substances are acid and relatively poor in nutrients and bases and subject to eluviation when drained. The mineral fraction is variable.

O IHS = HS horizon with a high percentage of mineral particles (clay, silt and sand). The mineral fraction is more than $50 \%$ (Fig. 8). Even if reported only among the Histic organic horizons, IHS can be an organic ( $C \geq 20 \%)$ or an organic-mineral $(C<20 \%)$ diagnostic horizon. The mineral 
component may occur in the form of thin layers. It characterises superficial more or less aerated soils (above all fens), with bioactivity comparable to zoHS. In always submerged river, lake or sea beds we find reduced grey/greenish Aqueous or Para anaOA inhabited by aquatic organisms, Archea and anaerobic bacteria.

\subsection{Histic organic-mineral horizons}

Submerged and/or water-saturated for a protracted period of the year (usually more than 6 months per year); carbon content between 7 and $20 \%$ of $70{ }^{\circ} \mathrm{C}$ - dried weight soil, in dry samples without living roots (Method: element analyser; ISO 10694, 1995).

\subsubsection{Histic organic-mineral (anA, from $A$ horizon and anmoor)}

Histic organic-mineral horizon mostly formed by microorganisms (actinomycetes), dark coloured, with plastic and massive structure, both high and low base-saturated (Fig. 9). Meso and microfauna may be abundant during aerated periods, but the typical structure of their droppings is rapidly destroyed by water immersion and permanence, which allows this horizon to be distinguished from gA in case of similar carbon content. Because of long periods of immersion, the oxidation of organic matter is slow, conferring it a dark colour due to partially oxidized organic matter in the soil. When needed, a detailed investigation with finer subdivisions could be made under local circumstances (Delft et al., 2002).

With the aim of avoiding confusion with Histic horizons, we reproduce here down the definition of two diagnostic horizons of Aqueous and Para humus systems:

- Aqueous or Para organic and/or organic-mineral horizon (anaOA) = [ana = anaerobic, from Greek an (without), aer (air) and bios (life)] organic and/or organic-mineral horizon and formed by the deposition of organic and mineral particles suspended in water. Never emerged OA horizon. Plant roots possible (Seagrasses). First phases of biological formation of sea and ocean floors, river beds. They can show even zoological activity due to bentic organisms (crustaceans, molluscs and aquatic worms). Possible in Aqueous systems over an anaA horizon (detailed in Humusica 2, Article 12); specific to Para Anaero humus system (detailed in Humusica 2, Article 13).

o Aqueous or Para organic-mineral horizon (anaA) $=[$ ana $=$ anaerobic, from Greek an (without), aer (air) and bios (life)] organic-mineral horizon and formed by the deposition and transformation of organic and mineral particles suspended in water. Never emerged A horizon. Plant roots possible (Seagrasses). Iron oxides always in reduced greyish/greenish form (Fe2O3). Slow process of anaerobic bio-transformation of organic matter in place. They can show even zoological activity due to bentic organisms (crustaceans, molluscs and aquatic worms). When the volume of mineral particles estimated by the naked eye in fresh samples is larger than $90 \%$ of the horizon volume, the horizon is labelled anaAC. Generated by the evolution of an anaOA horizon. Sea and ocean floors, large river beds. 


\section{Histic humus systems overview}

As for terrestrial humipedons, it is possible to individuate humus systems and forms. The classification of Histic humipedons closely resembles that of peat soils in main soil taxonomies (AFES, 2009; Soil Survey Staff, 2014; IUSS Working Group WRB, 2015). This is not surprising given that a peat soil is nothing more than a humus form in which the impeded decomposition of organic matter is the dominant feature of soil development. The classification of peat soils is in that sense a humus form classification "avant la lettre". Selecting the right master diagnostic horizons, a few main SYSTEMS are distinguished in order to separate Histic humipedons along a gradient of increasing biodegradation rate (Table 1 ).

Another table (Table 2) shows the grouping of diagnostic horizons and the consequent genesis of Aqueous, Histic, Intergrades and Terrestrial humus systems.

People accustomed to FAO/WRB manuals may use the following step-by-step keys for classifying Histic Humus systems:

o Anmoor: to be identified as Anmoor humus system, the humipedon must display the following properties: presence of a dominant anA organo-mineral horizon; and

zoHS, IHS possible but never thicker than anA.

o Saprimoor: to be identified as Saprimoor humus system, the humipedon must display the following properties:

HF or HM never present within the control section; and presence of zoHS or IHS at the top of the profile; and nozHS possible but thinner than zoHS; and

very active biodegradation of plant remains and their complete integration in an organicmineral horizon.

o Amphimoor: to be identified as Amphimoor humus system, the humipedon must display the following properties:

zoHS horizon dominant in thickness and present with $\mathrm{HF}$ or $\mathrm{HM}$ or HF and HM; and

$\mathrm{HF}$ and HM thinner than zoHS within the control section (first $40 \mathrm{~cm}$ below the surface); and

active to very active biodegradation of organic matter and mixing with organic-mineral matter.

o Mesimoor: to be identified as Mesimoor humus system, the humipedon must display the following properties:

HF possible but never dominant; and 
$\mathrm{HM}$ or nozHS present and thicker than other horizons; and organic matter degradation more active than in Fibrimoor.

o Fibrimoor: to be identified as Fibrimoor humus system, the humipedon must display the following properties:

presence of a thick HF horizon; and

HM possible but never thicker than $\mathrm{HF}$; and

degradation of organic matter slow or inhibited.

The name of a humus system is always written with capital letters, or with a beginning capital letter and in a single word.

Example: FIBRIMOOR or Fibrimoor; not Fibri Moor; not Fibri-Moor; not fibrimoor

A comparison of diagnostic characteristics and features of the different Histic humus systems is given in Fig. 10. A complete description of them, with a subdivision in more detailed Histic humus forms, is furnished in Humusica 2, article 10: Histic humus systems and forms - Key of classification.

\section{Authors' contribution}

Zanella A., De Waal R., Van Delft B., Ponge J.F.: coordination of authors' contribution, conception of the article, redaction, definition of basic vocabulary.

Jabiol B., De Nobili M., Ferronato C., Gobat J.M., Vacca A.: participation to discussions and improvement of the text.

\section{Content}

Article essence: Basic vocabulary and diagnostic characteristics and features necessary for the field classification of submerged humi- pedons

Rapid lecture: Look at Fig. 1 and Table 2.

\section{References}

AFES, 2009. Référentiel Pédologique 2008. Quae, Paris. 
Delft, S.P.J. van, Kemmers, R.H., de Waal, R.W., 2002. Ecologische typering van bodems onder korte vegetaties; het humusprofiel als graadmeter voor stand-plaatsontwikkeling. Landschap: tijdschrift voor landschapsecologie en milieukunde 19 (3), 152-164.

Green, R.N., Trowbridge, R.L., Klinka, K., 1993. Towards a taxonomic classification of humus forms. For. Sci. Monogr. 29, 1-49.

IUSS Working Group WRB, 2015. World Reference Base for Soil Resources 2014, update 2015: International soil classification system for naming soils and creating legends for soil maps. World Soil Resources Reports No. 106. FAO, Rome.

Levesque, M., Dinel, H., 1977. Fiber content, particle size distribution and some related properties of four peat materials in Eastern Canada. Can. J. Soil Sci. 57, 187-195.

Levesque, M., Dinel, H., Marcoux, R., 1980. Évaluation des critères de différentiation pour la classification de 92 matériaux tourbeaux du Québec et de l'Ontario. Can. J. Soil Sci. 60, 479486.

Soil Survey Staff, 2014. Keys to Soil Taxonomy by Soil Survey Staff, twelfth ed. United States Department of Agriculture, Natural Resources Conservation Service, Washington, DC.

Zanella, A., Jabiol, B., Ponge, J.F., Sartori, G., De Waal, R., Van Delft, B., Graefe, U., Cools, N., Katzensteiner, K., Hager, H., Englisch, M., 2011a. A European morpho-functional classification of humus forms. Geoderma 164, 138-145.

Zanella, A., Jabiol, B., Ponge, J.F., Sartori, G., De Waal, R., Van Delft, B., Graefe, U., Cools, N., Katzensteiner, K., Hager, H., Englisch, M., Brêthes, A., Broll, G., Gobat, J.M., Brun, J.J., Milbert, G., Kolb, E., Wolf, U., Frizzera, L., Galvan, P., Koli, R., Baritz, R., Kemmers, R., Vacca, A., Serra, G., Banas, D., Garlato, A., Chersich, S., Klimo, E., Langohr, R., 2011b. European Humus Forms Reference Base. http://hal.archivesouvertes.fr/docs/00/56/17/95/PDF/Humus Forms ERB 3101 2011.pdf. (Accessed 8 November 2016). 


\section{Figure captions}

Fig. 1. Relationships between Aqueous, Histic, Terrestrial and transitional Epihistic and Hydro humus systems.

Fig 2. Fibric component of histic organic horizons. More than $90 \%$ of the horizon volume is made of fibric component, i.e. of non-decomposed remains.

Fig 3. Sapric component of histic organic horizons. More than $70 \%$ of the horizon volume is made of sapric component, i.e. of well-decomposed remains.

Fig. 4. Histic organic horizons HF, HM and HS. Graphical definition showing the percent of fibric and sapric materials present in each of them. Three types of HS horizon are also illustrated, related to fauna activity and content in mineral fraction.

Figs. 5-8. (5) Histic HF horizon of a Fibrimoor, made of Sphagnum submerged remains. (6) Histic HM horizon in which neither fibric nor sapric components dominate.(7) Histic zoHS horizon, sapric material more than 70 of volume of dead material. (8) Histic IHS horizon, corresponding to sapric and mineral mixed materials, with mineral material $>50 \%$ in volume.

Fig. 9. Histic anA horizon, under a carpet of Chrysosplenium oppositifolium in a small wet area periodically nourished by a spring, and overlying a clayish impermeable substrate.

Fig. 10. Simplified field guide for comparing diagnostic characters of different Histic humus systems and forms (Authors: De Waal R., Zanella A.). 
Table 1

Diagnostic horizons and features of five biological activity SYSTEMS of Histic humipedons.

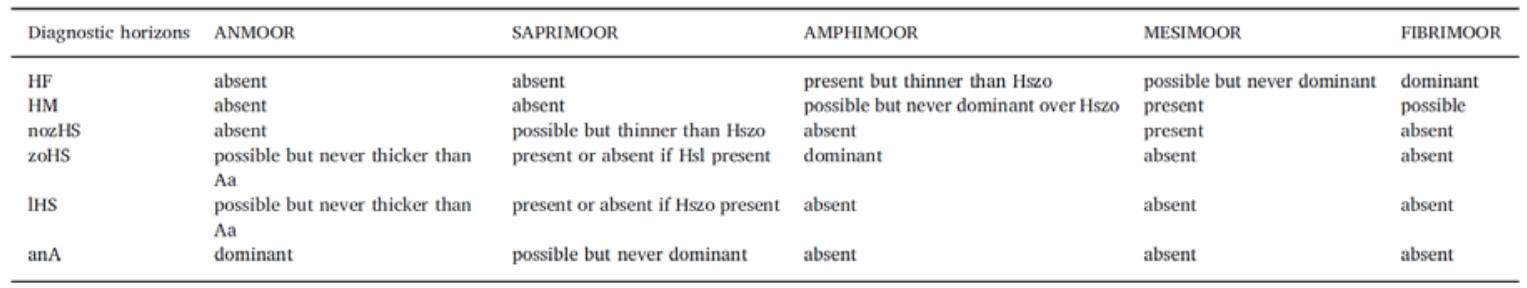

Table 2

Diagnostic horizons in Aqueous, Histic, Intergrades and terrestrial humus systems.

\begin{tabular}{|c|c|c|c|c|c|}
\hline Diagnostic horizons & \multicolumn{2}{|l|}{ Submerged } & \multicolumn{2}{|l|}{ Intergrade prefixes } & Terrestrial \\
\hline Only hydromorphic & & & & $\begin{array}{l}\text { gA or nozgA or } \\
\text { gAE }\end{array}$ & \\
\hline Hydromorphic and Histic & & & $\begin{array}{l}\text { H or anA AND } g A \text { or } \\
\text { nozgA or } \mathrm{gAE}\end{array}$ & & \\
\hline Anaero, hydromorphic, Histic & $\begin{array}{l}\text { anaOA, anaA, possible in addition: } \\
\mathrm{H} \text {, rarely: } \mathrm{gA}, \text { nozgA, } \mathrm{gAE}\end{array}$ & & & & \\
\hline
\end{tabular}




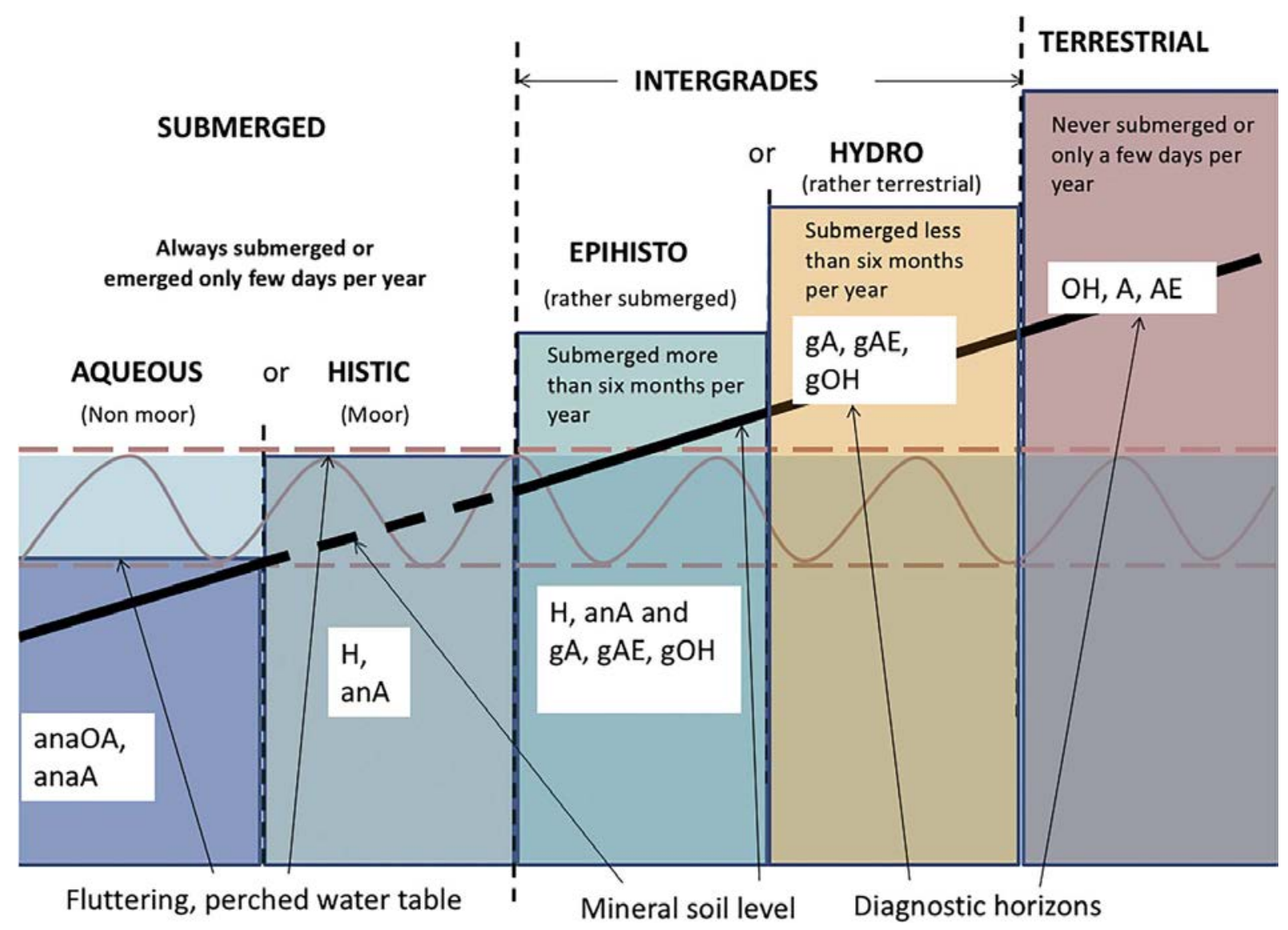

Fig. 1 


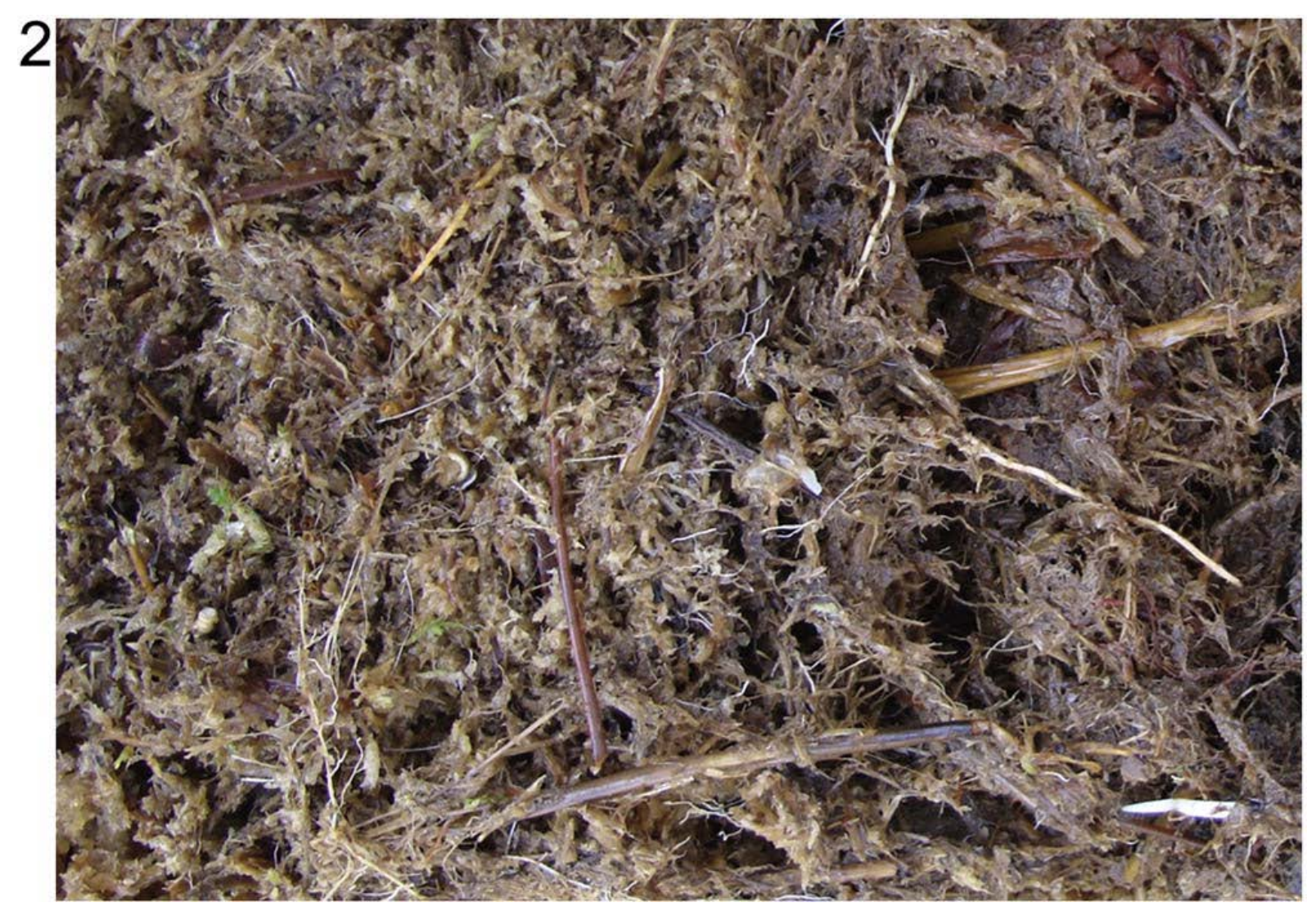

Fig. 2 


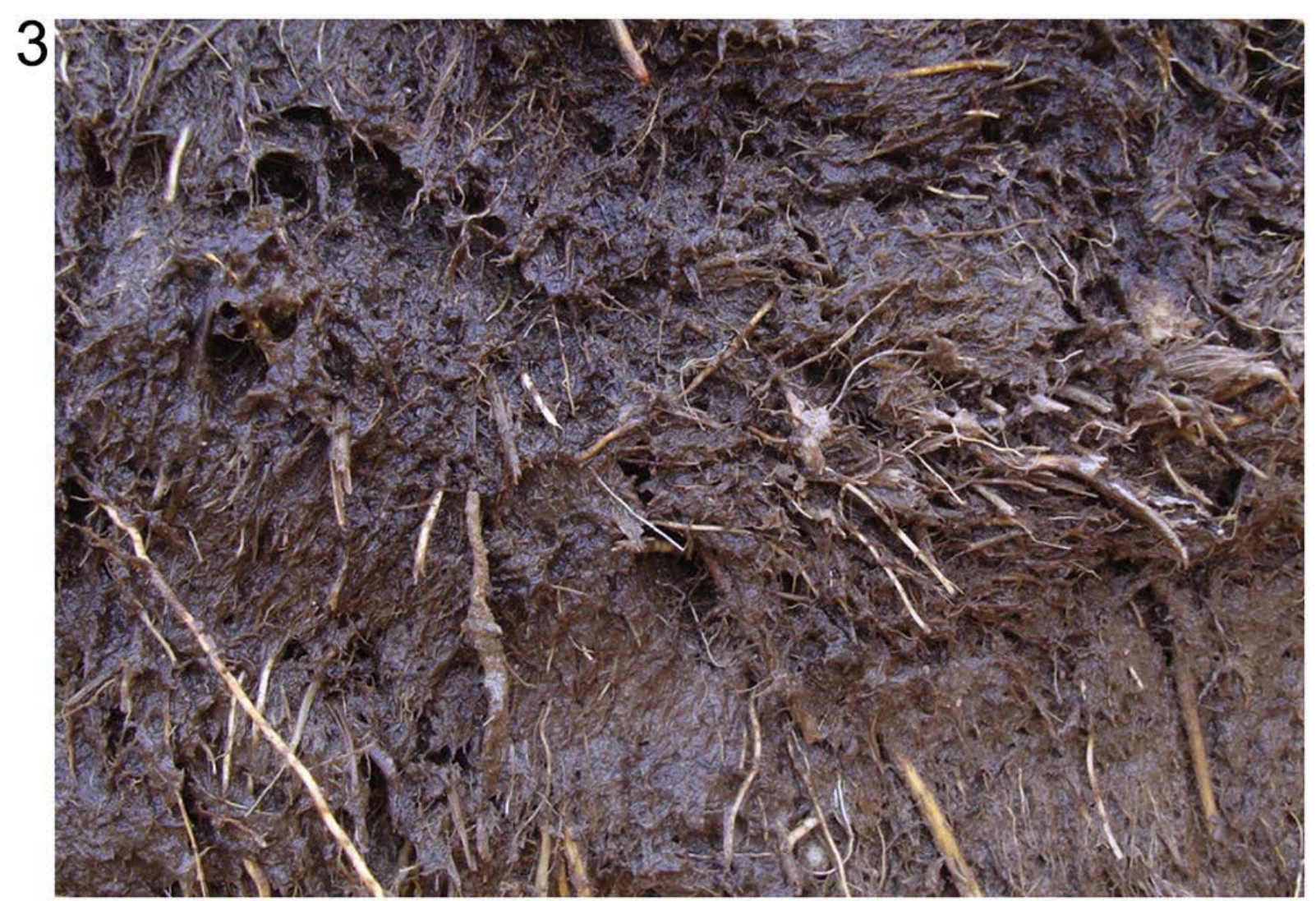

Fig. 3 

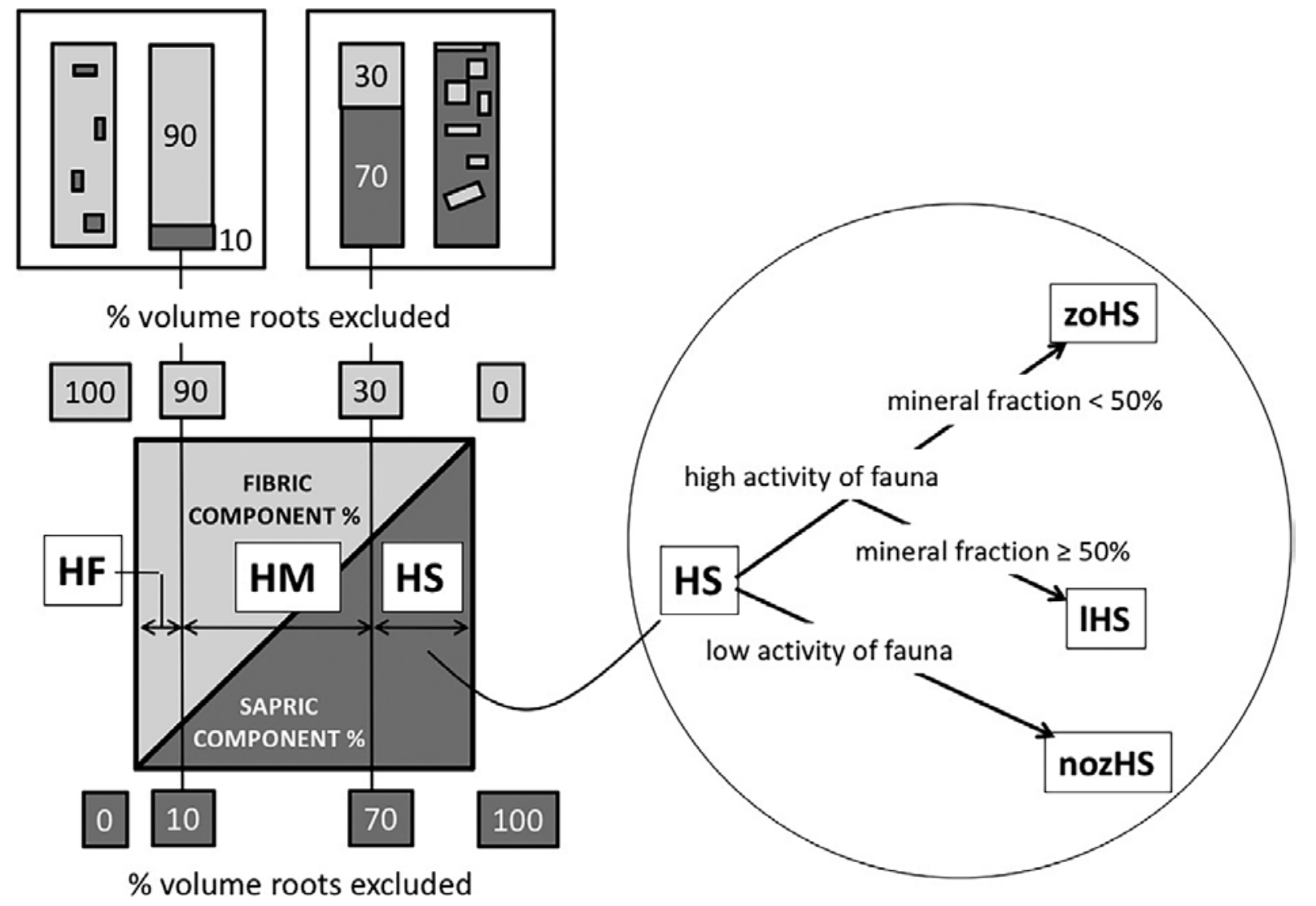

Fig. 4 

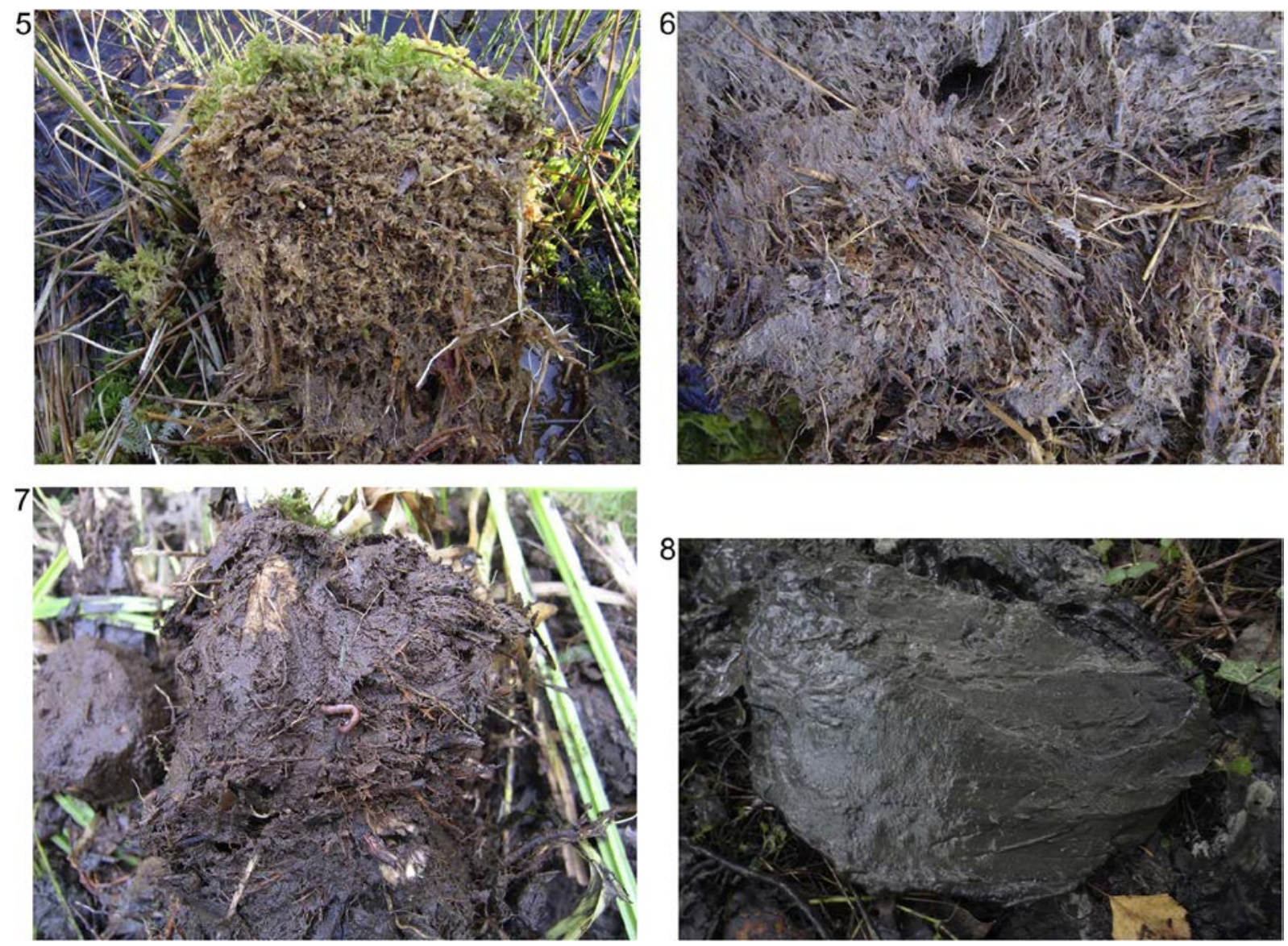

Figs. 5-8 


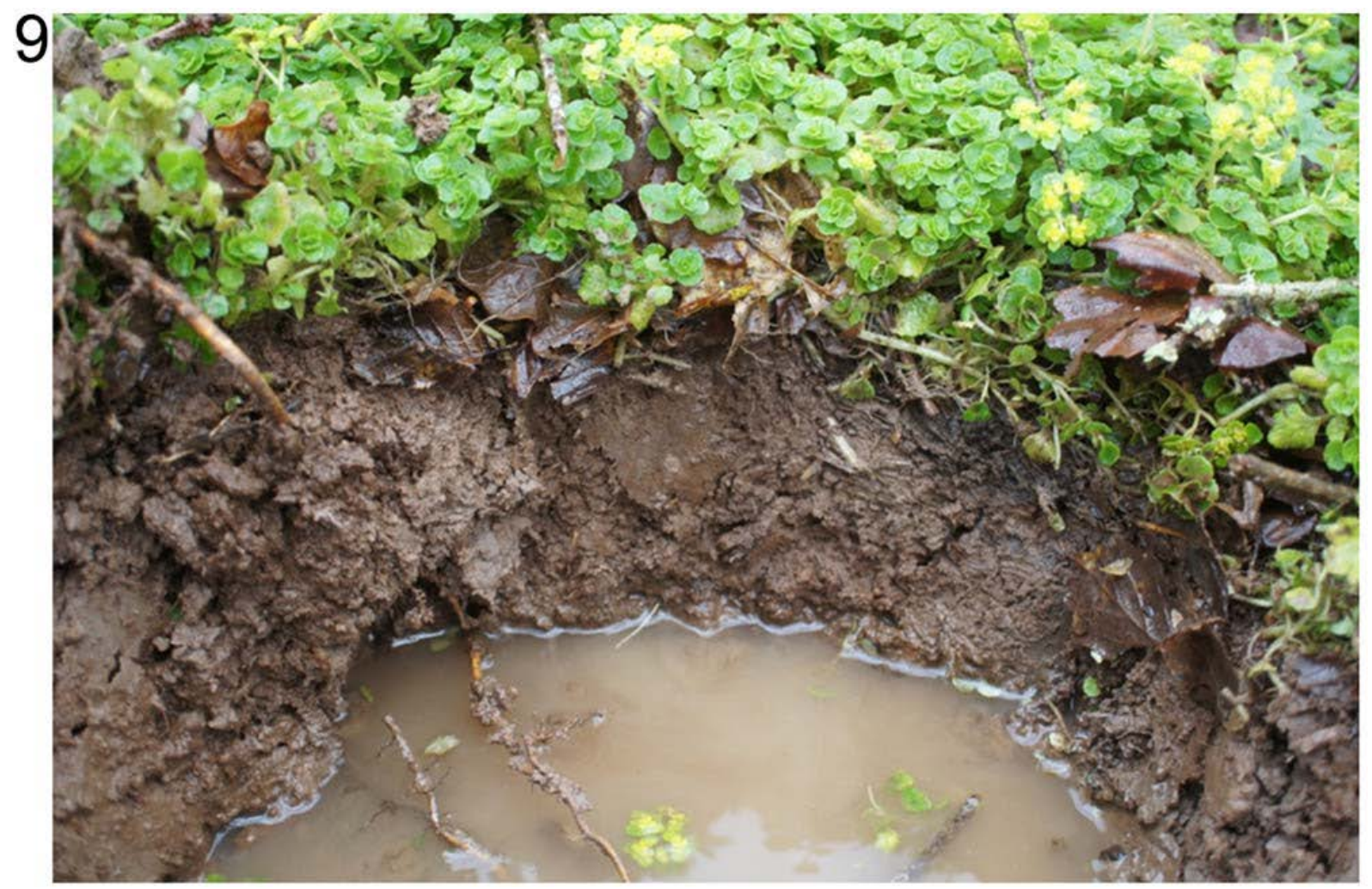

Fig. 9 


\section{Histic humus forms}

Supplementary diagnostic character related to vegetation: plant remains of aquatic or semiterrestrial species permanently water saturated or drained $\mathrm{H}$-layer dominant within a control section of $\mathbf{4 0} \mathbf{~ c m}$.

\begin{tabular}{|c|c|c|c|c|c|}
\hline HF dominant & HM dominant & \multirow[b]{2}{*}{$\leftarrow$} & \multicolumn{2}{|l|}{ HS dominant } & anA dominant \\
\hline$\longleftrightarrow$ & $\longleftrightarrow$ & & & $\rightarrow$ & $\longleftrightarrow$ \\
\hline $\begin{array}{l}\text { No mixing, low } \\
\text { humification low } \\
\text { mineralization }\end{array}$ & $\begin{array}{l}\text { No mixing, high } \\
\text { medium } \\
\text { humification and } \\
\text { low } \\
\text { mineralization }\end{array}$ & $\begin{array}{l}\text { No mixing high } \\
\text { humification, low } \\
\text { mineralization }\end{array}$ & $\begin{array}{l}\text { Medium mixing } \\
\text { and high } \\
\text { humification, } \\
\text { medium } \\
\text { mineralization }\end{array}$ & $\begin{array}{l}\text { High mixing, } \\
\text { humification and } \\
\text { medium to high } \\
\text { mineralization }\end{array}$ & $\begin{array}{l}\text { No mixing, high } \\
\text { humification, } \\
\text { medium to low } \\
\text { mineralization }\end{array}$ \\
\hline \multicolumn{2}{|c|}{$\begin{array}{l}\mathrm{HF}(\mathrm{S}) \text { on watery layer (floating } \\
\text { fens, quagmires) on nozHS or } \\
\text { waterstagnating parent rock }\end{array}$} & $\begin{array}{l}\text { nozHS, } \\
\text { massive } \\
\text { structure }\end{array}$ & $\begin{array}{l}\text { HF and/or HM } \\
\text { subdominant }\end{array}$ & $\begin{array}{l}\text { zoHS or IHS no } \\
\text { other horizons } \\
\text { within the } \\
\text { control section }\end{array}$ & $\begin{array}{l}\text { massive } \\
\text { structure }\end{array}$ \\
\hline & nozHS & & & HS & \\
\hline Fibrimoor & Mesimoor & Mesimoor & Amphimoor & Saprimoor & Anmoor \\
\hline $\begin{array}{l}\text { Eufibri: } \\
\mathrm{HF}\end{array}$ & Fibrimesi: & $\begin{array}{l}\text { Saprimesi: } \\
\text { nozHS }>H M\end{array}$ & $\begin{array}{l}\text { Fibriamphi: } \\
\mathrm{HS}>\mathrm{HF}\end{array}$ & $\begin{array}{l}\text { Eusapri: } \\
\text { zoHS }\end{array}$ & $\begin{array}{l}\text { Euan: } \\
\text { anA }\end{array}$ \\
\hline $\begin{array}{l}\text { Humifibri: } \\
\mathrm{HF}>\mathrm{HM}\end{array}$ & $\begin{array}{l}H M>H F>H S \\
\text { Eumesi: }\end{array}$ & $\begin{array}{l}\text { Humimesi: } \\
H M>n o z H S\end{array}$ & $\begin{array}{l}\text { Euamphi: } \\
\mathrm{HS}>\mathrm{HM}\end{array}$ & $\begin{array}{l}\text { Limisapri: } \\
\text { IHS }\end{array}$ & $\begin{array}{l}\text { Limian: } \\
\text { an } A>I H S\end{array}$ \\
\hline $\begin{array}{l}\text { Saprifibri: } \\
\mathrm{HF}>\text { nozHS }>\mathrm{HM}\end{array}$ & $\mathrm{HM}>\mathrm{HS}>\mathrm{HF}$ & & $\begin{array}{l}\text { Humiamphi: } \\
\mathrm{HS}>2 \mathrm{HM}\end{array}$ & $\begin{array}{l}\text { Oligosapri: } \\
\text { nozHS }\end{array}$ & $\begin{array}{l}\text { Saprian: } \\
\text { an } A>H S\end{array}$ \\
\hline
\end{tabular}

Fig. 10 